\title{
Etnomatematika: Eksplorasi Candi Borobudur
}

\author{
Rahmi Nur Fitria Utami, Dedi Muhtadi, Nani Ratnaningsih \\ Program Studi Pendidikan Matematika, FKIP, Universitas Siliwangi, Tasikmalaya, Indonesia \\ E-mail: dedimuhtadi@unsil.ac.id \\ Sukirwan \\ Program Studi Pendidikan Matematika Universitas Sultan Ageng Tirtayasa, Serang, Indonesia \\ Hasan Hamid \\ Program Studi Pendidikan Matematika Universitas Khairun, Indonesia
}

\begin{abstract}
ABSTRAK
Matematika merupakan ilmu tentang pola, struktur dan bentuk yang terintegrasi dalam budaya masyarakat. Konsep-konsep matematika yang diaplikasikan, merujuk pada aktivitas, kebiasaan, ataupun adat kehidupan masyarakat dalam menyelesaikan masalah disebut etnomatematika. Salah satu aplikasi etnomatematika ini terdapat pada Candi Borobudur. Candi Borobudur adalah megastruktur konseptual matematika yang dibangun sejak berabad-abad tahun yang lalu, dimana pada masa itu belum berkembang teknologi modern. Penelitian ini bertujuan untuk membahas tentang ajaran, filosofi, dan konsep matematika yang terdapat dalam Candi Borobudur, serta hubungan dari ketiganya. Penelitian ini menggunakan metode eksploratif dengan pendekatan historis dan kultural. Simpulan penelitian ini adalah sebagai berikut: (1) Candi borobudur sebagai produk etnomatematika menyajikan berbagai konsep agama, moral, budaya, dan matematika, (2) Secara keseluruhan, konsep-konsep tersebut memiliki hubungan dan keterkaitan diantara satu sama lain, (3) Konsep-konsep yang disepakati dan diterapkan dalam realita kehidupan, telah membawa matematika sebagai produk budaya yang tertanam sejak zaman dahulu meskipun mereka tidak menyadarinya, dan (4) Candi borobudur merupakan contoh monumen dari orkesta matematika dalam bentuk etnomatematika.
\end{abstract}

Kata Kunci: Candi Borobudur; Etnomatematika; Konsep Matematika

\begin{abstract}
Math is the science about the patterns, structures, and shape, integrated into the culture of the life of the community. Mathematical concepts which applicated in the cultural community, refer to activities or customs, habits, life incomplete the problem is called ethnomathematics. One of these ethnomathematics application is present on the Borobudur Temple. Borobudur Temple is a conceptual mathematical megastructure that was built centuries years ago, which at the time was notyet developing modern technology. The purpose of this study is to discuss the form of teaching, philosophy and mathematical patterns of the structure of the building of the temple, as well as the relationship of the third focus of the study. This research method using exploratory with historical and cultural approaches. The conclusions of this research are as follows: (1) Borobudur temple as ethnomatematics product presents various religious, moral, cultural, and mathematical concepts, (2) Overall, these concepts have a relationship and interrelationships with each other, (3) Concepts which are agreed upon and applied in the reality of life, have brought mathematics as a cultural product that has been embedded since ancient times even though they were not aware of it, and (4) Borobudur temple is an example of a monument of a mathematical orchestra in the form of ethnomatatics.
\end{abstract}

Keywords: Borobudur Temple; Ethnomathematics, Mathematical Concepts

\section{PENDAHULUAN}

Matematika merupakan pengetahuan yang bersifat universal dan menjadi dasar dalam pengembangan ilmu pengetahuan dan teknologi, serta berperan penting dalam memajukan daya pikir manusia untuk menyelesaikan berbagai persoalan dan telah menjadi bagian dari kehidupan manusia. Dengan demikian, matematika menjadi suatu hal yang melekat dan tidak terlepas dari kehidupan manusia, baik di rumah, di lingkungan kerja, di sawah, di kebun, di hutan, di ladang, di gunung, dan dimanapun mereka berada. Namun, terkadang 
masyarakat tidak menyadari bahwa mereka telah melakukan sebuah aktivitas matematika, karena matematika berkembang dari proses berpikir. Hal ini menunjukkan bahwa logika dijadikan sebagai dasar berkembangnya matematika yang membantu manusia dalam memahami dan menyelesaikan permasalahan, baik ekonomi, sosial, maupun alam. Oleh karena itu, matematika tidak hanya bersifat teoritis yang tertuang dalam secarik kertas, tetapi sejatinya telah tertanam dalam akal dan diolah oleh pikiran manusia sebagai anugerah Tuhan dan dipraktekkan dengan indera manusia dalam aktivitas kehidupan nyata.

Secara historis, perkembangan matematika memiliki catatan sejarah panjang. Banyak konsep matematika dikontribusi oleh budaya dalam kehidupan manusia. Budaya merupakan sesuatu yang kompleks, mengacu pada unsur keyakinan, pengetahuan, kesenian, moral, hukum, adat, kemampuan, dan kebiasaan lain yang dimiliki manusia sebagai bagian dari masyarakat (Tylor, 2016). Matematika lahir, tumbuh, dan berkembang dari budaya, dimana budaya tersebut menjadi bagian dari kehidupan manusia yang tidak terlepas dari satu zaman ke zaman berikutnya. Sehingga muncullah pengertian bahwa matematika merupakan produk budaya yang menyatu dalam kehidupan masyarakat yang disebut dengan istilah etnomatematika (Muhtadi, Sukirwan, \& Warsito, 2019). Etnomatematika adalah aktivitas matematika yang dilakukan oleh sekelompok budaya masyarakat tertentu, seperti kelompok buruh, tani, nelayan, anak-anak dari masyarakat kelas tertentu, kelas professional, dan lain-lain (D’Ambrosio, 1985; Gerdes, 1994). Oleh karena itu matematika merupakan suatu bentuk budaya yang terintegrasi dalam kehidupan masyarakat, kapanpun dan dimanapun mereka berada (Muhtadi, Sukirwan, Warsito, \& Prahmana, 2017; Hermanto, Wahyudin, \& Nurlaelah, 2019).

Pengertian "kapanpun dan dimanapun", mengindikasi bahwa matematika tidak hanya diterapkan pada masa modern, tetapi sesungguhnya telah tertanam sejak zaman nenek moyang tanpa mereka sadari. Pada zaman prasejarah, mereka telah menerapkan beberapa konsep matematika sederhana. Sebagai bukti, ditemukannya tulang lelombo di Pegunungan Lelombo, Swaziland, sebagai benda matematika tertua yang dimungkinkan berasal dari tahun 35.000 SM. Tulang ini berisi 29 goresan berbeda pada tulang fibula baboon, yang menjelaskan dan membuktikan bahwa kaum wanita pada masa itu telah menerapkan kebiasaan menghitung untuk mengingat siklus haid mereka, yaitu 28 sampai 30 goresan. Penemuan ini membuktikan bahwa ketika belum ada teknologi, nenek moyang sudah dapat menggunakan akal dan pikiran mereka untuk menyelesaikan suatu permasalahan dengan menggunakan peralatan yang sederhana, dan hal tersebut merupakan esensi dari matematika. Mungkin tidak disadari bahwa mereka telah dapat menerapkan konsep matematika walaupun dalam tingkat yang sederhana.

Indonesia adalah negeri yang kaya akan ragam budayanya dan produk etnomatematika telah banyak ditemukan di berbagai suku dan etnis, di seluruh penjuru tanah air (Fitriani, Somatanaya, Muhtadi, \& Sukirwan, 2019; Nisa, Nurjamil, Muhtadi, \& Sukirwan, 2019). Tetapi masih banyak etnomatematika yang belum terkupas dan masih perlu digali, salah satunya adalah etnomatematika Candi Borobudur. Candi Borobudur adalah candi yang diperkirakan dibangun sekitar abad ke-8 Masehi pada zaman wangsa Syailendra dan menjadi salah satu warisan dunia milik Indonesia (Soekmono, 1976, p.9; United Nations Educational, Scientific and Cultural Organization [UNESCO], 2014). Perkiraan pembangunan Candi Borobudur ini berlangsung selama 75 - 100 tahun, dan selesai pada masa Raja Samaratungga, dimana tulisan pada relief candi borobudur ini secara paleografis sangat mirip dengan tulisan pada Prasasti Kayumwungan, bertanggalkan tahun 746 Saka atau 824 Masehi (Sundberg, 2008; Munoz, 2007; Panyadewa, 2014, p.26). 
Dilihat dari struktur bangunan Candi Borobudur yang megah, dengan bentuk dan pola bangunan yang unik, memberikan makna tersendiri tentang bagaimana masyarakat pada zaman dahulu menghasilkan sebuah karya besar berupa candi yang sangat megah dan sarat dengan konsep matematika. Padahal diketahui bahwa pada masa itu belum ada teknologi yang berkembang seperti saat ini. Konsep matematika tanpa disadari telah diaplikasikan dan menjadi aktivitas dalam kehidupan masyarakat zaman dahulu.

Penelitian-penelitian mengenai Candi Borobudur yang telah dilakukan dewasa ini, lebih menitikberatkan pada konsep matematika sebagai hasil merancang bangunan, mengukur, membuat pola, serta bagaimana mengaitkan konsep-konsep matematika tersebut dalam pembelajaran matematika (Danoebroto, 2017; Pardimin, 2018). Penelitian yang menitikberatkan pada kajian tentang ajaran, filosofi, dan konsep matematika belum banyak dikaji. Terutama dari segi matematis, yaitu struktur bangunan berupa relief, arca, dan stupa. Ditinjau dari segi filosofis, ada pesan moral dan budaya, dan dari segi spiritual, ada ajaran agama yang disampaikan oleh Candi Borobudur. Oleh karena itu, penulisan artikel ini bertujuan untuk membahas tentang ajaran, filosofi, dan konsep matematika yang terdapat dalam Candi Borobudur, serta hubungan dari ketiganya.

\section{METODE PENELITIAN}

Penelitian ini menggunakan metode eksploratif dengan pendekatan historis dan kultural. Metode eksploratif bertujuan untuk menggali secara luas tentang sebab-sebab atau hal-hal yang mempengaruhi terjadinya sesuatu, bersifat terbuka, mencari unsur-unsur, ciri-ciri dan sifat-sifat dari objek penelitian (Arikunto, 2010, p.7). Pendekatan historis bertujuan untuk merekonstruksi fenomena masa lampau secara sistematis dan objektif, dengan mengumpulkan, mengevaluasi, memverifikasi, dan mensintesiskan bukti-bukti untuk menegakkan fakta guna memperoleh kesimpulan yang akurat (Sjamsuddin, 2012; Priyadi, 2012; Daliman, 2015). Dan pendekatan kultural dilakukan pada sebuah objek berupa unsur atau gejala budaya dengan menggunakan perangkat metodologis yang tercakup dalam ilmu pengetahuan budaya (Denzin \& Lincoln (Eds.), 2009).

Fokus penelitian ini berkaitan dengan ajaran agama, pesan moral, budaya, dan pola matematis yang terdapat dalam Candi Borobudur. Secara geografis, Candi Borobudur berlokasi di Jalan Badrawati, Kecamatan Borobudur, Kabupaten Magelang, Provinsi Jawa Tengah, Indonesia.

Ajaran, pesan, dan pola matematis diperoleh dari penelitian-penelitian sebelumnya berdasarkan catatan sejarah dari berbagai sumber, sehingga diperoleh data-data yang kemudian dikumpulkan dan dievaluasi untuk melihat keteraturan pola, esensi dan substansi yang terdapat pada Candi Borobudur. Selanjutnya, data-data tersebut dianalisis untuk mengungkap ajaran agama, filosofi dan konsep matematika, serta hubungan dari ketiganya dalam etnomatematika Candi Borobudur.

\section{HASIL DAN PEMBAHASAN}

Ajaran Agama yang Terdapat dalam Candi Borobudur. Temuan arkeologis menyatakan bahwa pada tahun 700-900 Masehi, Jawa Tengah merupakan pusat kerajaan Hindu dan Buddha. Hal ini sesuai dengan kesepakatan para ahli yang menyatakan bahwa pembangunan Candi Borobudur terjadi sekitar tahun 700-900 Masehi. Oleh karena itu candi ini identik dengan ajaran agama Hindu-Budha (Utomo, 2011). 
Candi adalah bangunan kuno terbuat dari batu sebagai tempat pemujaan, penyimpanan abu jenazah raja-raja dan pendeta Hindu-Buddha pada zaman dahulu. Pada masa modern, pengertian candi merujuk kepada tempat beribadah peninggalan peradaban Hindu-Buddha dan biasa difungsikan sebagai tempat memuliakan Buddha (Dumarcay, 2007). Bangunan Candi Borobudur terdiri dari enam platform persegi dan di atasnya terdapat tiga platform melingkar yang dihiasi dengan 2.672 panel relief dan 504 patung Buddha (Soekmono, 1976, pp.35-36). Candi Borobudur tidak hanya memiliki luas struktur bangunan secara fisik, tetapi juga menyimpan ajaran Budha yang disampaikan melalui simbol-simbol pada arca, relief, dan stupa.

Struktur bangunan Candi Borobudur terdiri dari tiga bagian, yaitu: kepala, badan, dan kaki. Bagian-bagian Candi Borobudur ini memiliki makna berbeda dan berhubungan secara tersirat berdasarkan konsep Buddhisme, yaitu fase perkembangan jiwa dan episode kehidupan Sang Buddha (UNESCO, 2005; UNESCO, 2014; Nagaoka, 2016; Suamba, 2016).

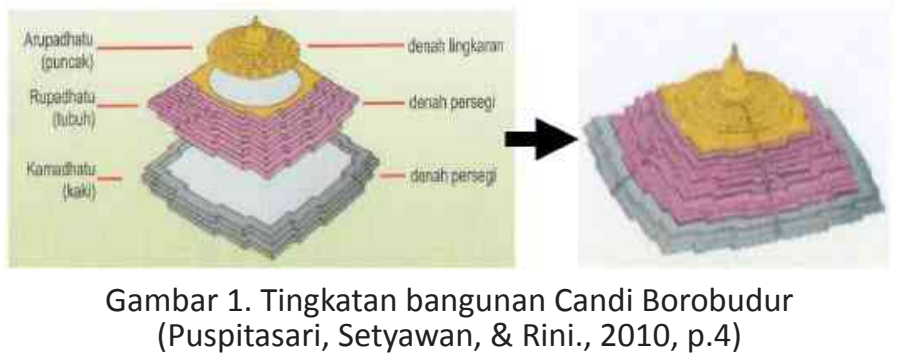

Kaki candi disebut Kamadhatu, sebagai dasar bangunan candi dan berisi 160 panel. Bagian ini menggambarkan alam pertama dari ketiga lapis tingkat kesadaran spiritual manusia menurut konsep Buddhisme yang disebut Kamadhatu atau alam hawa nafsu, dimana karakter binatang mendominasi kepribadian yang dimiliki manusia (Larisa, 2011, p.18). Pada bagian ini terdapat relief yang memuat kisah Karmavibhangga, menggambarkan perjalanan hidup manusia di dunia, dimana manusia masih dikuasai oleh hawa nafsu dan persiapan mental yang harus diraih sebelum mencapai tujuan akhir, yaitu terbebas dari ikatan duniawi (UNESCO, 2005).

Badan candi disebut Rupadhatu, berisi 1.300 panel yang menyiratkan "alam antara", yaitu tahap dimana manusia dapat mengalahkan keinginannya dan muncul kecenderungan mulia, namun mereka masih terpengaruh oleh karakteristik manusia yang khas (Larisa, 2011, p.19). Di badan candi terdapat empat lorong. Pada lorong pertama dinding candi berisi 740 panel, mengisahkan cerita: (1) Lalitavistara, penggambaran kisah hidup Sidharta Gautama sebagai pendiri Agama Buddha, dari beliau lahir hingga mencapai tempat dimana Sang Buddha melakukan semedi dan memperoleh pencerahan yang disebut Boddhi, (2) Jataka, menggambarkan Sang Buddha sebelum terlahir sebagai Siddharta Gautama, dan (3) Avadana, menggambarkan tentang orang-orang suci (UNESCO, 2005). Pada lorong kedua dinding candi berisi 228 panel, mengisahkan Sudhana yang ingin mengetahui tentang boddhi. Pada lorong ketiga dinding candi berisi 176 panel, menggambarkan kisah Gandavyuha, yaitu tentang ketekunan dan usaha yang tak kenal lelah untuk mencapai tujuan akhir (UNESCO, 2005). Dan pada lorong keempat dinding candi berisi 156 panel, juga mengisahkan cerita Gandavyuha.

Kepala candi disebut Arupadhatu (alam atas), merupakan alam para dewa atau tingkatan tertinggi yang melambangkan kekosongan, kedamaian dan ketentraman, alam spiritual tanpa hawa nafsu dan keinginan (Larisa, 2011, p.20). Tingkatan ini menggambarkan seseorang dalam perjalanan hidupnya jika melakukan kebajikan selangkah demi selangkah akan mencapai puncak, yaitu boddhi atau tingkat tertinggi. 
Ajaran agama Buddha yang terdapat dalam Candi Borobudur tidak hanya ditemukan pada tingkatan bangunannya saja, tetapi juga tersimpan dalam simbol-simbol yang terdapat pada relief, arca, dan stupa. Relief pada Candi Borobudur mengisahkan ajaran yang disampaikan oleh Sang Buddha bahwa Candi Borobudur sebagai tempat belajar tentang kehidupan manusia. Seperti terlihat pada dinding Kamadhatu terdapat relief yang menggambarkan bagaimana Buddha mengajarkan perihal hukum sebab akibat dari perbuatan baik dan jahat (Suamba, 2016).

(a)

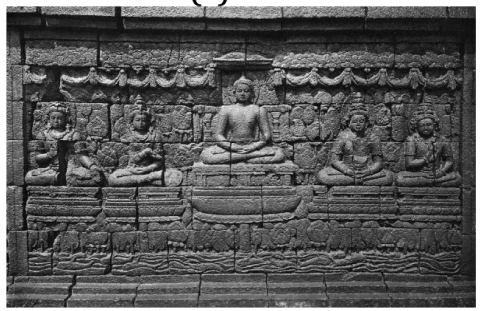

(b)

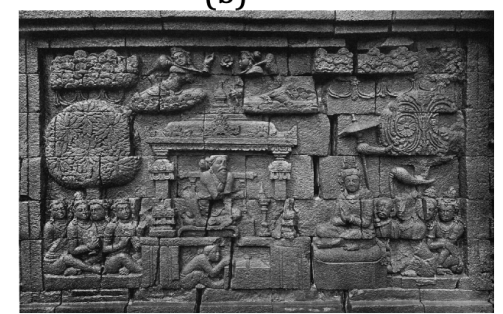

Gambar 2. (a) Relief Budha, (b) Relief Sudhana (Fointen, 2012)

Arca pada Candi Borobudur menyimpan ajaran tentang karakteristik Sang Buddha yang menunjukkan keluhuran, kehormatan, dan keagungan (Panyadewa, 2014, p.84). Salah satu karakter fisik, yaitu: (1) Kepala bagian ubun-ubun menonjol menandakan pencapaian spiritual Buddha dan simbol pencerahan, (2) Urna adalah bulu halus yang tumbuh diantara kedua alis, melambangkan kebijaksanaan spiritual yang dikaitkan dengan mata ketiga, yaitu mata batin untuk melihat sifat alami dunia sebagaimana adanya, (3) Daun telinga panjang, menggambarkan kemajuan spiritual Buddha (McArthur, 2002, p.93), (4) Mata Buddha setengah terpejam, melambangkan konsentrasi, (5) Mulut tertutup dan senyum tipis, menandakan kebenaran hidup, tenang, damai, dan membawa kesejukan hati, dan (6) Baju kain, melambangkan Buddha telah meninggalkan hal-hal duniawi (Panyadewa, 2014).

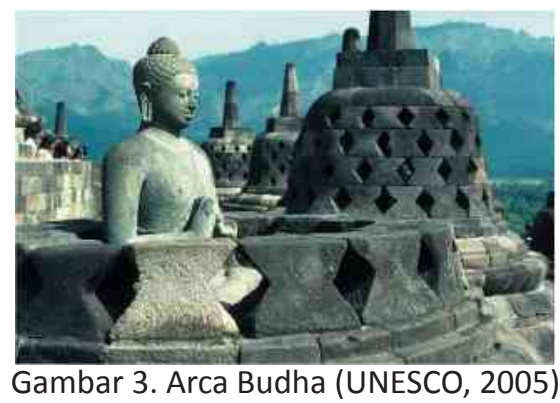

Pada arca Buddha terdapat mudra, yaitu sikap tubuh berupa sikap tangan yang bersifat simbolis dalam ritual Buddhisme untuk melambangkan makna spiritual khusus (Panyadewa, 2014, p.93; Larisa, 2011, p.28). Dalam Ajaran Buddha terdapat istilah Dhyani Buddha, yang melambangkan lima aspek kebenaran (Dharmakaya) dari sikap seorang Buddha (Panyadewa, 2014, pp.102-103).

Tabel 1. Enam Mudra Arca Buddha (Hidayat, Sunarto, \& Guntur, 2014)

\begin{tabular}{|c|c|c|c|}
\hline Arca & Dhyani Buddha & Letak & Makna \\
\hline Bhumisparsa mudra & Aksobhya & Timur & $\begin{array}{l}\text { Sikap tangan menghadap ke bawah, tangan } \\
\text { kiri terbuka dan menengadah di pangkuan, } \\
\text { tangan kanan menempel pada lutut kanan } \\
\text { dengan jari-jari menunjuk ke bawah. } \\
\text { Melambangkan Sang Buddha memanggil } \\
\text { Dewi Bumi sebagai saksi ketika dia } \\
\text { menangkis serangan iblis Mara. }\end{array}$ \\
\hline
\end{tabular}




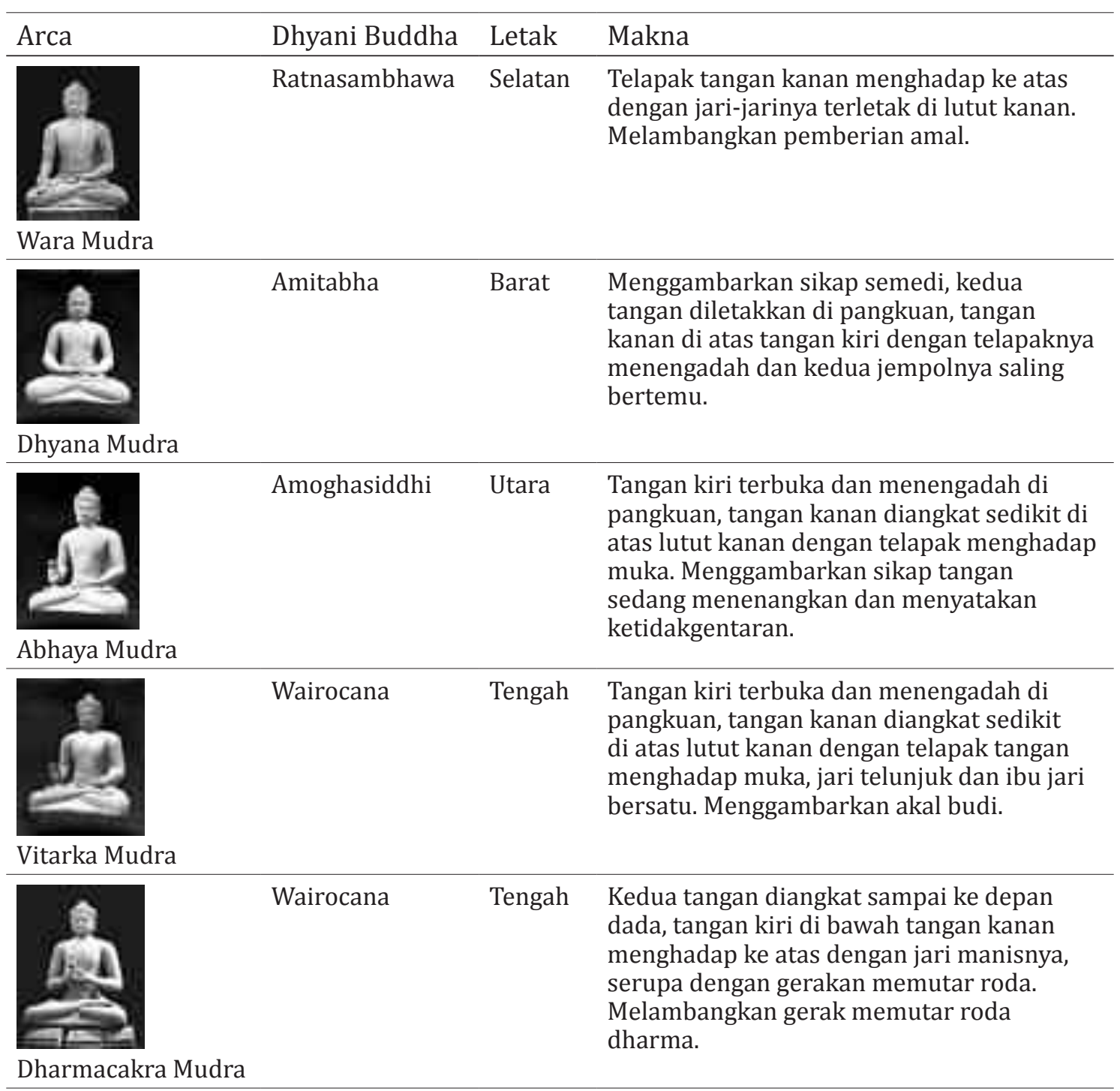

Stupa adalah bangunan yang terbuat dari batu berbentuk menyerupai genta, sebagai bangunan suci agama Buddha dan tempat menyimpan relik atau benda-benda suci sang Buddha yang telah ada sejak zaman pra-Buddhis di India (Panyadewa, 2014, p.174). Stupa didirikan sebagai tempat menyimpan relik, simbol pemikiran Sang Buddha dan pencerahan tertinggi. Tujuan menyimpan relik berhubungan dengan keyakinan bahwa adanya hubungan yang tidak terpisahkan antara ruh orang yang sudah meninggal dengan bagian tubuhnya (Panyadewa, 2014, p.175). Stupa pada Candi Borobudur memiliki makna sebagai wujud pengakuan terhadap Buddhisme di wilayah Borobudur (Kementrian Pendidikan dan Kebudayaan [Kemendikbud], 2001). Selain itu, keberadaan stupa ini menjadi petunjuk seberapa luas ajaran Buddhisme tersebar di wilayah tersebut.

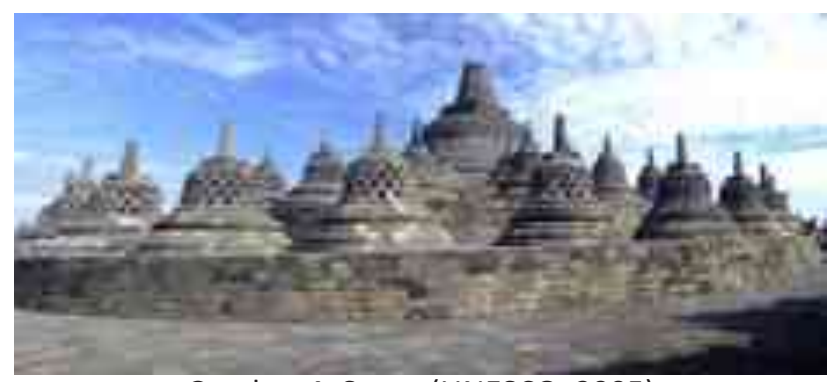

Gambar 4. Stupa (UNESCO, 2005) 
Pesan Moral dan Budaya dalam Candi Borobudur. Secara filosofi, pemahaman ajaran Budha sebagai petunjuk pesan moral terdapat pada pahatan tentang cerita-cerita yang memuat kisah Karmavibhangga, Lalitavistara, Avadana, Jataka, dan Gandavyuha pada seluruh relief Candi Borobudur (Magetsari, 1997, p.11; Panyadewa, 2014, p.111). Apabila ditelusuri cerita pada relief secara keseluruhan searah jarum jam, akan diperoleh kesatuan cerita yang berisi pesan mengenai kehidupan manusia. Secara tersirat cerita tersebut menggambarkan tentang kehidupan manusia, jika berbuat baik akan mendapat imbalan yang baik di akhirat, dan sebaliknya, perbuatan buruk akan mendapat imbalan yang buruk pula (Panyadewa, 2014, p.145). Begitu pula relief pada dinding Kamadhatu, menjelaskan hukum karma dari perbuatan manusia yang dilakukan pada masa hidupnya (Suamba, 2016).

Ditinjau dari segi budaya, keberadaan Candi Borobudur menyiratkan makna bahwa etnomatematika telah berkembang pada masa itu, dimana konsep matematika digunakan untuk membangun Candi Borobudur dan menjadi budaya berupa aktivitas dalam kehidupan manusia. Selain itu, terdapat pesan bahwa Candi Borobudur sebagai wujud budaya klasik Jawa dalam bentuk struktur bangunan candi. Bahkan dunia telah menetapkan Candi Borobudur sebagai warisan dunia (World Cultural Heritage) dalam kategori budaya tahun 1990.

Konsep Matematika Berupa Pola Matematis pada Candi Borobudur. Konsep matematika pada Candi Borobudur ditunjukkan oleh bentuk struktur bangunan menyerupai konsep bangun datar dan bangun ruang dalam matematika. Hakikat Candi Borobudur adalah sebuah stupa. Jika dilihat dari atas berbentuk pola mandala besar, yaitu susunan pola yang terdiri atas bujur sangkar dan lingkaran konsentris yang melambangkan alam semesta (Wayman, 1981).

(a)

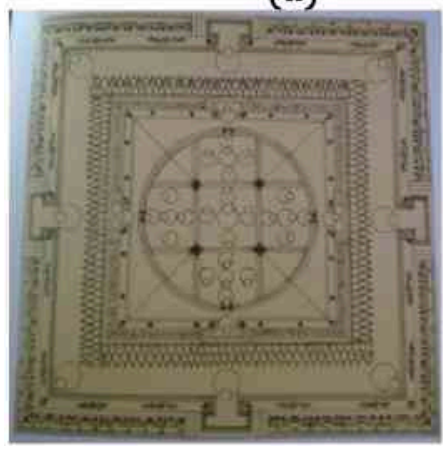

(b)

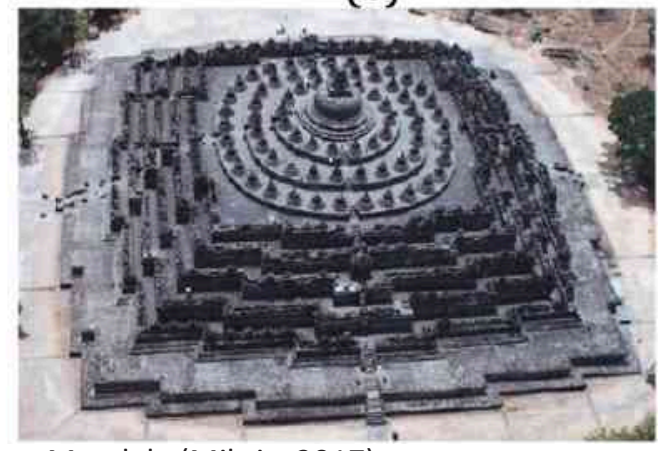

Gambar 5. (a) Diagram Mandala (Miksic, 2017),

(b) Aerial Photography Candi Borobudur (UNESCO, 2005)

Konsep desain Candi Borobudur dapat dikaitkan dengan Euclidean Geometry. Struktur bangunan Candi Borobudur terdiri dari dua bentuk utama, yaitu lingkaran dan persegi. Merujuk pada bentuk utama tersebut dapat diperoleh beberapa konsep dasar bangunan Candi Borobudur berkaitan dengan geometri, yaitu bangun datar, bangun ruang, dan fraktal. Selain itu, dilihat dari keterpaduan antar bagian bangunan, dapat diperoleh beberapa konsep matematika lainnya, yaitu bilangan, perbandingan, penjumlahan, dan teselasi.

Konsep bangun datar dapat dilihat dari bentuk bangunan dasarnya, yaitu Candi Borobudur terdiri dari 10 tingkat, dimana tingkat 1 hingga 6 berbentuk persegi dan sisanya berbentuk lingkaran (Lihat gambar 1). Pada relief yang terdapat pada dinding candi, ada yang menyajikan bentuk bangun datar, seperti lingkaran, persegi panjang, segitiga, persegi, dan jajargenjang. 
(a)

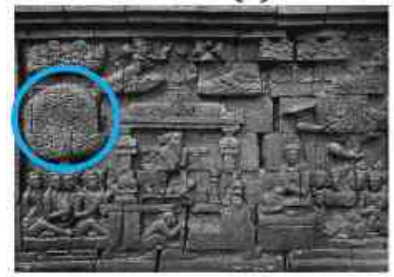

(d)

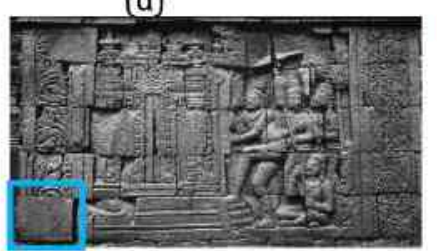

(c)

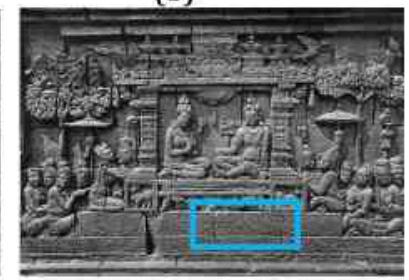

(e)
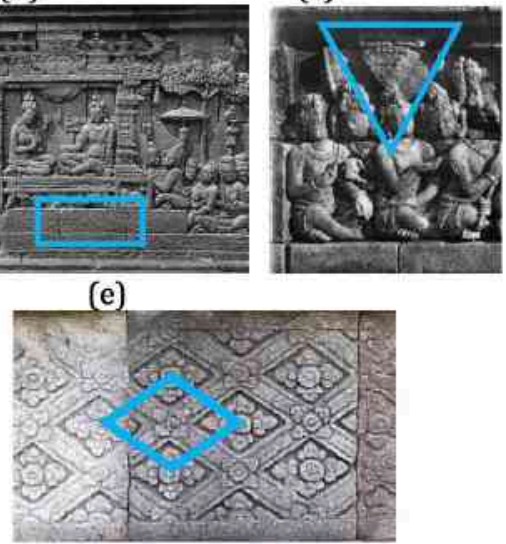

Gambar 6. Relief yang memuat bangun datar lingkaran, persegi panjang, segitiga, persegi, dan jajargenjang (Fointen, 2012)

Konsep bangun ruang ditemukan pada relief dan stupa Candi Borobudur. Bentuk stupa Candi Borobudur menyerupai bangun ruang kerucut dalam matematika, ditandai oleh bagian dasar lingkaran dan semakin ke atas semakin mengerucut hingga puncak. Selain itu, terdapat bangun ruang balok dan kubus pada relief dinding Candi Borobudur.

(a)

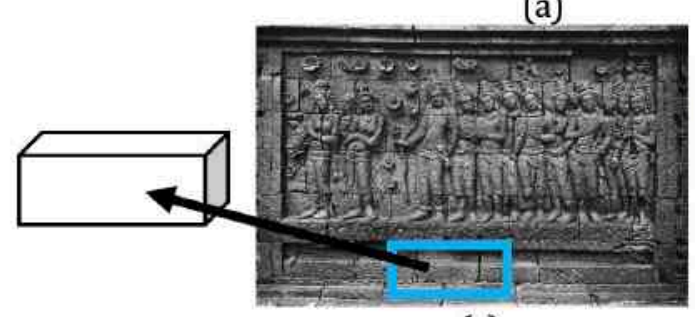

(c) (b)

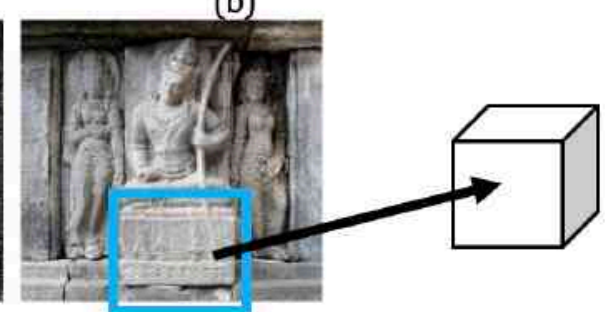

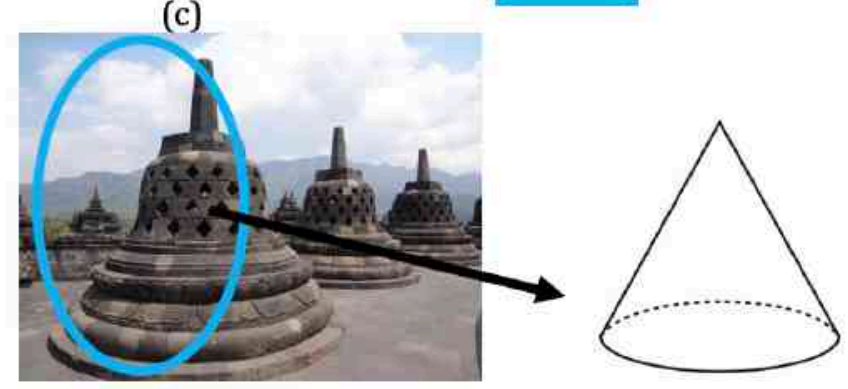

Gambar 7. (a) Relief berbentuk balok (Fointen, 2012), (b) Relief berbentuk kubus, dan (c) Stupa berbentuk kerucut (Suwardhi, Menna, Remondino, Hanke, \& Akmalia, 2015).

Konsep geometri fraktal juga terdapat pada Candi Borobudur. Fraktal adalah bentuk geometris dengan detail tak terbatas dan strukturnya sangat kompleks, memiliki beberapa ukuran kesamaan diri, dimana setiap bagian di dalamnya merupakan skala kecil dari keseluruhan bagian (Licker, 2003, p.90; Downing, 2009, p.134; Clapham \& Nicholson, 2009, p.327). Candi Borobudur terlihat berupa sebuah stupa yang sangat besar dan dikelilingi oleh stupa-stupa kecil, inilah yang dinamakan geometri fraktal (Lihat gambar 9).

Untuk menghitung dimensi fraktal pada Candi Borobudur dapat menggunakan metode boxcounting (Barnsley, 1988; Falconer, 2003). Metode box-counting dilakukan dengan membagi denah menjadi kotak-kotak dengan berbagai variasi ukuran. Sehingga diperoleh dimensi Candi Borobudur, yaitu (D) $=2,3252$. Berdasarkan hasil perhitungan tersebut, $2<D<3$, sehingga struktur bangunan Candi Borobudur bukan bangun ruang 3 dimensi maupun 2 dimensi, melainkan Candi Borobudur berada diantara dimensi 2 dan 3 (Situngkir, 2010). 
Apabila dilihat dari atas maupun dari samping, Candi Borobudur berbentuk geometri dimensi satu maupun dimensi dua yang berulang-ulang. Dilihat dari atas, bangunan ini terdiri dari persegi yang didalamnya terdapat persegi yang lebih kecil (rekursif). Pada tiga lantai teratas, terdiri dari lingkaran yang didalamnya juga terdapat lingkaran yang lebih kecil. Sedangkan jika dilihat dari samping, bangunan ini tersusun dari balok dan tabung yang menumpuk. Balok dan tabung dengan ukuran terbesar berada dibagian terbawah dan diatasnya terdapat balok atau tabung lain yang lebih kecil.
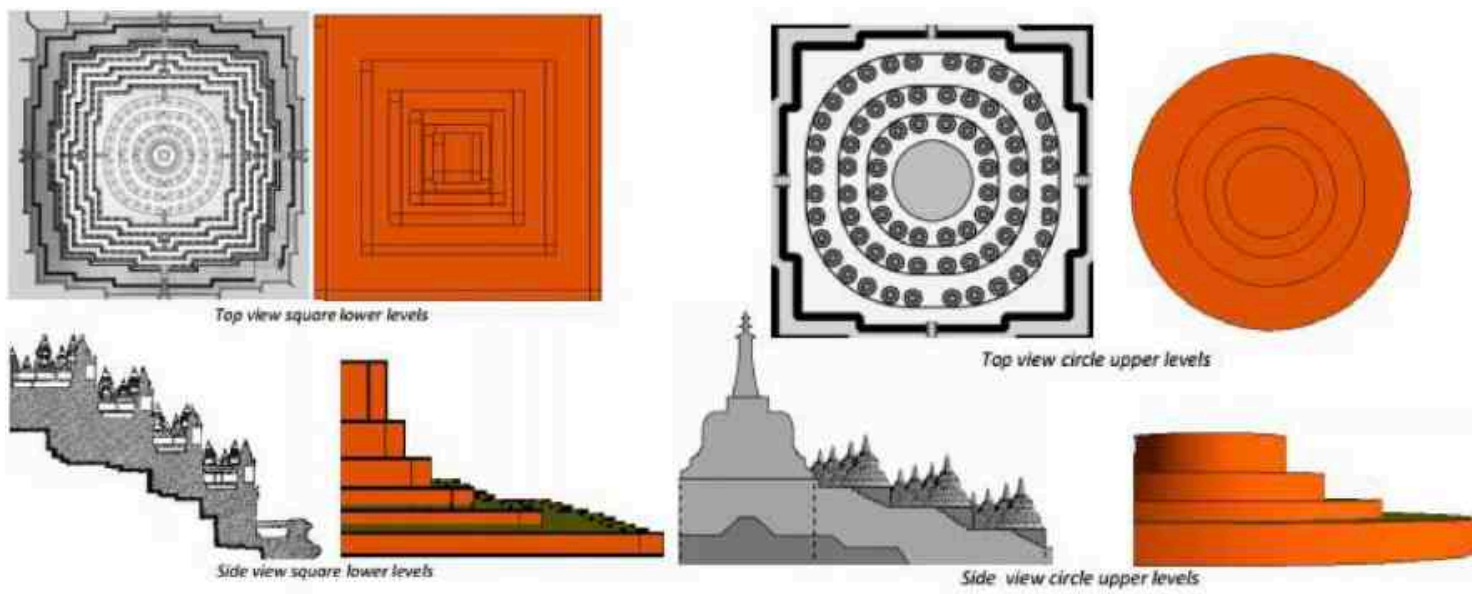

Gambar 8. Konsep bangun ruang pada Candi Borobudur jika dilihat dari atas dan samping (Situngkir, 2010)

Konsep matematika mengenai perbandingan dengan pola teratur juga terdapat pada Candi Borobudur. Hal ini terlihat dari jumlah stupa pada tingkat Arupadhatu, yaitu pada lantai 7 berjumlah 16 stupa, lantai 8 berjumlah 24 stupa, dan lantai 9 berjumlah 32 stupa (Larisa, 2011, p.20). Sehingga diperoleh perbandingan 16:24:32. Apabila semua nilai ini dibagi 8, maka nilai perbandingannya menjadi 2:3:4 yang tergolong perbandingan dengan pola yang teratur.

Konsep perbandingan lainnya pada Candi Borobudur, ditemukan pada ukuran tinggi dan diameter stupa, yaitu pada lantai 7 berukuran 1,7 meter, lantai 8 berukuran 1,8 meter, dan lantai 9 berukuran 1,9 meter. Sehingga diperoleh perbandingan 1,7:1,8:1,9 yang juga merupakan perbandingan yang teratur.

Selain itu, jika dilihat secara vertikal dan horizontal, bangunan Candi Borobudur memiliki perbandingan tertentu berdasarkan rasio kepala, badan, dan kaki, yaitu kaki berjumlah 4, badan berjumlah 6, dan kepala berjumlah 9. Sehingga diperoleh rasio 4:6:9. Rasio ini sesuai dengan konsep Hindu-Buddha dalam membangun kuil yang dihubungkan dengan bagian tubuh manusia (Situngkir, 2010; Panyadewa, 2014, p.193).

(a)

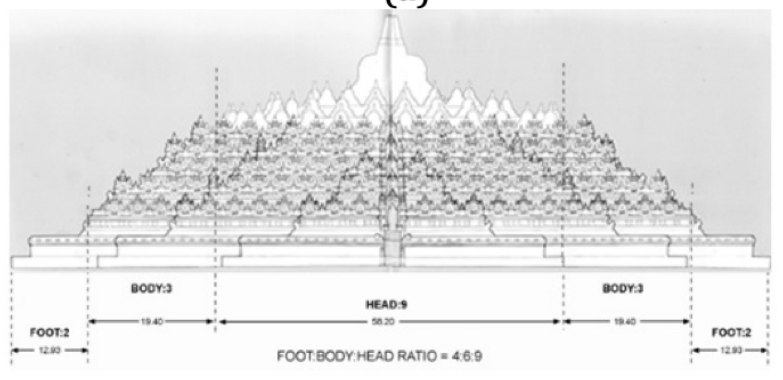

(b)

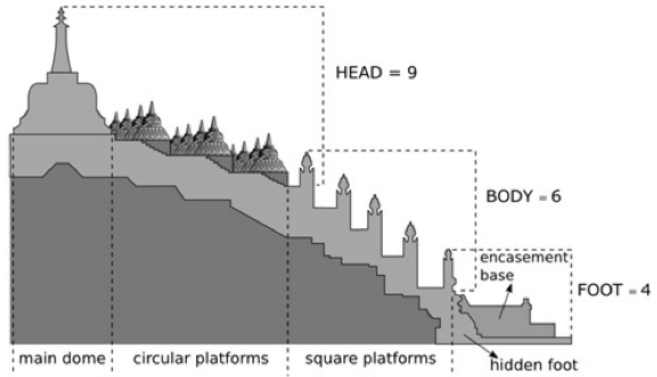

Gambar 9. (a) Borobudur secara horizontal, (b) Borobudur secara vertikal (Situngkir, 2010) 
Konsep matematika mengenai bilangan dan penjumlahan juga ditemukan pada Candi Borobudur. Secara matematis, arsitektur dari Candi Borobudur memiliki keunikan, yaitu jika angka-angka terkait Candi Borobudur dijumlahkan, maka akan menghasilkan angka 1, yaitu: (1) Jumlah tingkatan Candi Borobudur adalah 10, apabila angka-angka pada bilangan 10 ini dijumlahkan, hasilnya adalah $1+0=1$, (2) Jumlah stupa pada Candi Borobudur adalah $32+24+16+1=73$, jika angka-angka pada bilangan 73 ini dijumlahkan maka hasilnya $7+$ $3=10$, kemudian jika angka-angka pada bilangan 10 ini dijumlahkan hasilnya adalah $1+0=$ 1, dan (3) Jumlah patung dalam Candi Borobudur berjumlah 505 buah, apabila angka-angka pada bilangan ini dijumlahkan maka hasilnya adalah $5+0+5=10$, dan apabila angka-angka pada bilangan 10 dijumlahkan hasilnya adalah $1+0=1$.

Konsep bilangan lainnya pada Candi Borobudur adalah bilangan 432. Dikatakan bahwa seorang Bodhisattva tingkat ke-7 menguasai 37 faktor pencerahan, 3 pintu kebebasan, 4 cara penyelamatan, 4 kekuatan, dan 6 kesempurnaan. Semuanya berjumlah 54 aspek pencerahan. Jika bilangan 54 dikalikan dengan 8 penjuru mata angin, maka akan didapatkan angka 432. Hal ini sesuai dengan 432 jumlah arca Buddha yang mengelilingi Candi Borobudur di tingkat persegi ke-2 sampai ke-6 sebagai simbol aspek yang harus dikuasai seorang bodhisattva sebelum mencapai tingkat ke-7 (Kandahjaya, 2011, p.47; Panyadewa, 2014, p.198).

Apabila bilangan 432 dibagi dengan 4 penjuru, maka didapatkan angka 108 yang merupakan jumlah arca Buddha untuk masing-masing arah timur, barat, utara, dan selatan pada tingkat ke-2 hingga ke-6. Jumlah lubang masing-masing stupa teras melingkar di tingkat ke-8 dan ke-9 adalah 44, dan di tingkat ke-7 adalah 64. Apabila keduanya dijumlahkan $44+64=$ 108. Jumlah seluruh arca Buddha adalah 504, jika peziarah berjalan dengan pradaksina mengelilingi Borobudur lalu turun kembali dengan berkeliling lagi, maka akan melewati arca Buddha sebanyak 2 kali, yaitu $504 \times 2=1008$. Angka ini bermakna sama dengan 108 karena salah satu angka 0 tidak dihitung. Dalam agama Buddha, angka 108 melambangkan kesempurnaan yang dalam bahasa sansekerta "jaya" yang bermakna kemenangan atau keberhasilan (Panyadewa, 2014, p.199).

Dalam salah satu versi Vajradhatu Mandala terdapat 37 figur suci, yaitu 1 figur Mahavairocana di tengah dan 36 figur lain yang mengelilinginya. Jika bilangan 36 dikalikan 2, bilangan 36 pertama melambangkan Vajradhatu Mandala sebagai fenomena absolut dan 36 selanjutnya melambangkan Garbhadhatu Mandala sebagai cerminan dari fenomena relatif. Semua berjumlah 72 yang dilambangkan dengan 72 stupa berlubang di teras melingkar dan Mahavairocana dilambangkan dengan stupa induk. Dalam fisiologi Hindu-Buddha terdapat 101 arteri dan 72 vena dalam tubuh manusia. Arteri ke 101 adalah tulang belakang. Candi Borobudur memiliki 100 saluran air berbentuk makara yang dapat dilihat sebagai arteri Borobudur dan poros tengah bangunan sebagai arteri ke-101 (Panyadewa, 2014, p.200).

Angka 9 pada Candi Borobudur memiliki keunikan yang ditemukan dengan perhitungan matematika pada komponen yang terdapat dalam Candi Borobudur. Dalam agama Buddha, angka 9 memiliki beberapa arti, yaitu; (1) Dianggap sebagai angka dengan kekuatan spiritual tertinggi, (2) Buddha memiliki 9 kualitas yaitu yang Mahasuci (Araham), yang telah mencapai penerangan sempurna (Sammasambuddho), sempurna pengetahuan serta tindak tanduk-Nya (Vijjacaranaasampanno), sempurna menempuh Sang Jalan (Sugata), pengenal segenap alam (Lokavidu), pembimbing manusia yang tiada taranya (Anuttaro purisadammasarathi), guru para dewa dan manusia (Sattha Devamanussaman), yang sadar (Buddho), dan yang patut dimuliakan (Bhagava), (3) Latihan meditasi dalam agama Buddha Mahayana melewati 9 tahap melatih pikiran, 9 penghentian setelah bermeditasi, dan (4) Alam murni Buddha Amitabha bernama Sukhavati mempunyai 9 tingkat yang terbagi berdasarkan perkembangan spiritual penghuninya (Panyadewa, 2014, p.203). 
Tabel 2. Keunikan angka 9 pada Candi Borobudur (Panyadewa, 2014, p.203)

\begin{tabular}{lll}
\hline Deskripsi Bilangan & Bilangan & Hubungan dengan Angka 9 \\
\hline Jumlah semua arca Borobudur & 504 & $5+0+4=9$ \\
\hline Jumlah arca di atas pagar langkan & 432 & $4+3+2=9$ \\
\hline Jumlah arca di atas pagar langkan setiap arah & 108 & $1+0+8=9$ \\
\hline Jumlah anak tangga di semua arah & 360 & $3+6+0=9$ \\
\hline Jumlah arca di semua teras melingkar & 72 & $7+2=9$ \\
\hline Jumlah arca Buddha dibagi 8 & 63 & $6+3=9$ \\
\hline
\end{tabular}

Konsep matematika terakhir yang terdapat pada Candi Borobudur adalah teselasi. Teselasi adalah penyusunan berlapis oleh suatu bentuk poligon dimana seluruhnya memiliki bentuk dan ukuran yang sama (Licker, 2003, p.247). Sebagai contoh pada stupa Candi Borobudur terdapat kubus dengan ukuran $15 \mathrm{~cm} \times 15 \mathrm{~cm}$ sebanyak 36 buah yang diatur sedemikian rupa hingga memenuhi sebuah stupa. Dengan itu dapat diketahui luas permukaan seluruh kubus tersebut, yaitu $36 \times$ luas permukaan balok persegi $=36 \times(15 \times 15)=36 \times 225=8.100$ $\mathrm{cm}^{2}$.
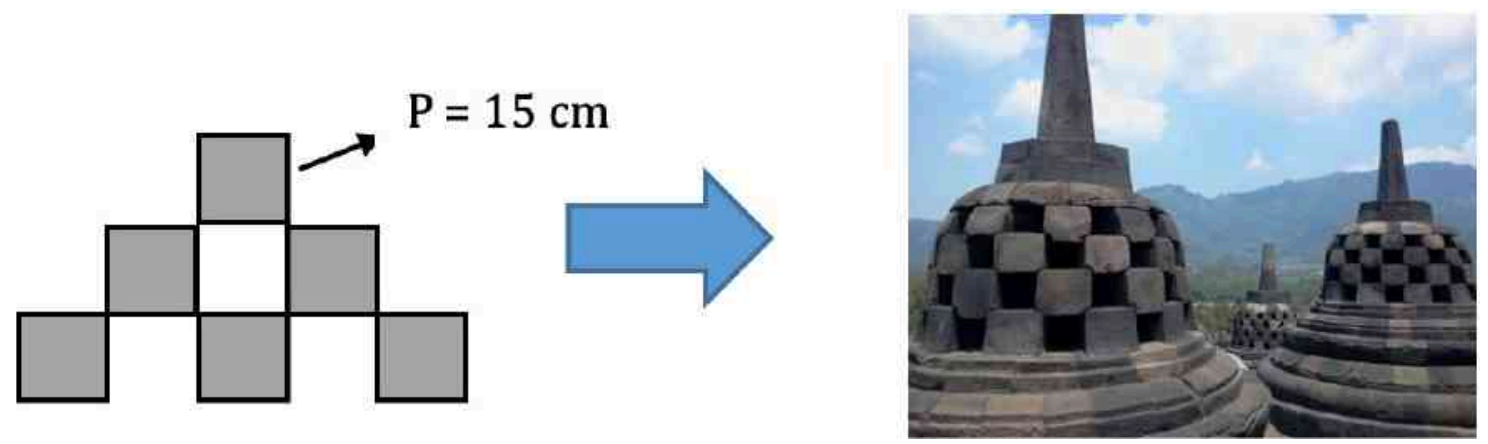

Gambar 10. Konsep teselasi pada Stupa (UNESCO, 2005)

Hubungan antara Ajaran, Filosofi, dan Konsep Matematika pada Candi Borobudur. Matematika adalah ilmu tentang pola, bentuk, dan struktur, yang diolah melalui proses berpikir, diorganisasikan, dan dibuktikan secara logis dengan menggunakan istilah bahasa yang cermat, jelas, dan akurat. Matematika bukan mengenai kepastian atau ketidakpastian, melainkan matematika berbicara tentang kesepakatan. Dalam matematika kepastian belum bisa diperoleh, kecuali berhubungan dengan angka 0 hingga 9. Sebuah kesepakatan membicarakan bahwa sebuah pernyataan adalah benar, jika apa yang dibicarakan itu memiliki nilai kebenaran. Inilah yang dimaksud dengan kesepakatan. Kesepakatan merupakan hasil olah matematika, dimana kesepakatan itu sebagai hasil berpikir dan olah logika yang diproses oleh akal dan pikiran. Hasil olah logika tersebut diperoleh melalui persamaan-persamaan untuk menghasilkan sebuah rumus kesepakatan yang ditulis dengan bahasa matematika. Sehingga dapat disimpulkan bahwa matematika tidak hanya berkaitan dengan hitungan, tetapi matematika merupakan bahasa yang mempengaruhi logika untuk menghasilkan sebuah kesepakatan.

Kesepakatan sebagai hasil berpikir matematik, ditemukan dalam ajaran dan filosofi yang terdapat pada Candi Borobudur. Ajaran Buddha yang telah dibahas sebelumnya merupakan hasil proses perjalanan hidup yang diterima Sang Budha dan merupakan kebenaran yang diyakini oleh para penganutnya. Filosofi merupakan hasil olah logika yang berhubungan dengan adat kebiasaan kehidupan manusia yang disampaikan melalui bahasa tersirat dalam bentuk simbol dan pola yang terstruktur, sehingga matematika merupakan sebuah bahasa yang mengkomunikasikan pesan moral dan budaya. Pesan moral dan budaya ini 
disepakati oleh masyarakat sebagai sebuah kebenaran dan merupakan pedoman hidup dalam melakukan aktivitas kehidupan sehari-hari.

Penelitian pada Candi Borobudur menyatakan bahwa ternyata terdapat hubungan antara ajaran, filosofi, dan konsep matematika yang membentuk bangunan Candi Borobodur menjadi sebuah megastruktur yang fenomenal. Bangunan Candi Borobudur merupakan realisasi konsep-konsep matematika yang terstruktur, unik, dan indah. Di setiap bagian dari struktur candi tersebut tersimpan pesan moral dan filosofi yang menggambarkan ajaran, budaya dan realita kehidupan pada masa pembangunannya. Konsep matematika, ajaran, dan filosofi ini menjadi satu kesatuan yang tidak dapat dipisahkan dari Candi Borobudur. Hubungan ini menginspirasi pemahaman tentang matematika sebagai orkestra dari kehidupan, dimana seluruh konsep itu bersatu dalam etnomatematika.

\section{SIMPULAN}

Berdasarkan hasil penelitian mengenai etnomatematika: eksplorasi candi borobudur, dapat disampaikan beberapa kesimpulan sebagai berikut: (1) Candi borobudur sebagai produk etnomatematika menyajikan berbagai konsep agama, moral, budaya, dan matematika, (2) Secara keseluruhan, konsep-konsep tersebut memiliki hubungan dan keterkaitan diantara satu sama lain, (3) Konsep-konsep yang disepakati dan diterapkan dalam realita kehidupan, telah membawa matematika sebagai produk budaya yang tertanam sejak zaman dahulu meskipun mereka tidak menyadarinya, dan (4) Candi borobudur merupakan contoh monumen dari orkesta matematika dalam bentuk etnomatematika.

\section{DAFTAR RUJUKAN}

Arikunto, S. (2010). Prosedur penelitian: Suatu pendekatan praktik (Rev. ed.). Jakarta, Indonesia: Rineka Cipta.

Barnsley, M.F. (1993). Fractals Everywhere (2nd Ed.). Cambridge, MA: Academic Press. doi: 10.1016/C2013-0-10335-2

Clapham, C. \& Nicholson, J. (2009). The Concise Oxford Dictionary of Mathematics (4th Edition). New York, NY: OUP Oxford.

Daliman, A. (2015). Metode Penelitian Sejarah. Yogyakarta, Indonesia: Ombak.

D'Ambrosio, U. (1985). Ethnomathematics and its Place in the History and Pedagogy of Mathematics. For the learning of Mathematics, 5(1), 44-48. Retrieved from https:// www.jstor.org/stable/40247876.

Danoebroto, S. W. (2017). Student's Perception on Borobudur Temple as Mathematic Learning Resource. Southeast Asian Mathematics Education Journal, 7(1), 77-87. Retrieved from https://www.qitepinmath.org/en/publications/journal/seamej-vol7-number-1-2017

Denzin, N. K. \& Lincoln, Y. S. (Eds.) (2009). Handbook of Qualitative Research. (Dariyatno, Trans.) Yogyakarta, Indonesia: Pustaka Pelajar.

Downing, D. (2009). Dictionary of Mathematics Term (3rd Ed.). New York, NY: Barron's Educational Series.

Dumarçay, J. (2007) Candi Sewu and Buddhist Architecture of Central Java. (W. Arifin \& H. Chambert-Loir ,Trans.). Jakarta Selatan, Indonesia: KPG (Kepustakaan Populer Gramedia).

Falconer, K. (2014). Fractal Geometry: Mathematical Foundations and Applications (3rd Ed). Hoboken, NJ: John Willey \& Sons. 
Fitriani, I. A., Somatanaya, A.A. G., Muhtadi, D., \& Sukirwan (2019). Etnomatematika: Sistem Operasi Bilangan Pada Aktivitas Masyarakat Jawa. Journal of Authentic Research on Mathematics Education (JARME), 1(2), 1-11. Retrieved from http://jurnal.unsil.ac.id/ index.php/jarme.

Fontein, J. (2012). Entering the Dharmadhatu: A Study of the Gandavyuha Reliefs of Borobudur. Leiden, The Netherlands: Brill.

Gerdes, P. (1994). Reflection on Ethnomathematics. For the Learning of Mathematics, 14(2), 19-22. Retrieved from https://www.jstor.org/stable/40248110.

Hermanto, R., Wahyudin., \& Nurlaelah, E. (2019). Exploration of ethnomathematics on the kampung naga indigenous peoples. Journal of Physics: Conference Series. doi: 10.1088/1742-6596/1315/1/012072.

Hidayat, I.K., Sunarto, P., \& Guntur, T. (2014). Mengenal Relief, Mudra dan Stupa Candi Borobudur untuk Anak-Anak Usia 9-12 Tahun melalui Edugame. Jurnal Visual, Seni, dan Desain, 6(1), 58-68. doi: 10.5614\%2Fitbj.vad.2014.6.1.6.

Kandahjaya, H. (2011). Kunci Induk untuk Membaca Simbolisme Borobudur. Jakarta Barat, Indonesia: Karaniya.

Kementrian Pendidikan dan Kebudayaan. (2001). Saving Chandi Borobudur for 1000 Years more - Final Report on The Restoration of Borobudur 1969-1982, Project Report. Jakarta, Indonesia: Ministry of Education and Culture of Indonesia.

Larisa. (2011). The Magnificence of Borobudur. Jakarta, Indonesia: Gramedia Pustaka Utama.

Licker, M.D. (2003). McGraw-Hill Dictionary of Scientific and Technical Terms, (6th Ed.). New York, NY: McGraw-Hill Education.

Magetsari, N. (1997). Candi Borobudur: Rekonstruksi Agama dan Filsafatnya. Jakarta, Indonesia: Fakultas Sastra Universitas Indonesia.

McArthur, M. (2002). Reading Buddhist Art: An Illustrated Guide to Buddhist Signs and Symbols. London, United Kingdom: Thames \& Hudson.

Miksic, J.N. (2017). Borobudur: Golden Tales of the Buddhas. North Clarendon, VT: Tuttle Publishing.

Muhtadi, D., Sukirwan, Warsito, \& Prahmana, R.C.I. (2017). Sundanese Ethnomathematics: Mathematical Activities in Estimating, Measuring, and Making Patterns. Journal on Mathematics Education, 8(2), 185-198. doi: 10.22342/jme.8.2.4055.185-198.

Muhtadi, D., Sukirwan, \& Warsito (2019). Ethnomathematics on Sundanese belief symbol. International Journal of Innovation, Creativity, and Change, 10(2), 44-55. Retrieved from https://www.ijicc.net/images/vol10iss2/10207_Muhtadi_2019_E_R.pdf

Munoz, P. M. (2007). Early Kingdoms of the Indonesian Archipelago and the Malay Peninsula. Kuala Lumpur, Malaysia: Didier Millet.

Nagaoka, M. (2016). Cultural Landscape Management at Borobudur, Indonesia. In Springer Brief in Archaeology. Switzerland, AG: Springer Nature. doi: 10.1007/978-3-31942046-2.

Nisa, F. F., Nurjamil, D., Muhtadi, D., dan Sukirwan (2019). Studi etnomatematika pada aktivitas urang sunda dalam menentukan pernikahan, pertanian dan mencari benda hilang. JP3M (Jurnal Penelitian Pendidikan dan Pengajaran Matematika), 5(2), 63-74. Retrieved from http://jurnal.unsil.ac.id/index.php/jp3m

Panyadewa, S. (2014). Misteri Borobudur: Candi Borobudur Bukan Peninggalan Nabi Sulaiman (E. Sulwesi, \& Shalahuddin Gh, Eds.). Jakarta, Indonesia: Dolphin.

Pardimin. (2018). Etnomatematika dalam Budaya Masyarakat Yogyakarta. Prosiding Seminar Nasional Pendidikan Matematika Etnomatesia. Retrieved from http://www. jurnal.ustjogja.ac.id/index.php/etnomatnesia

Priyadi, S. (2012). Metodologi Penelitian Pendidikan Sejarah. Yogyakarta, Indonesia: Penerbit Ombak. 
Puspitasari, D.E., Setyawan, H., \& Rini, W.D.P. (2010). Kearsitekturan Candi Borobudur. Kerjasama Antara Pusat Pengembangan Sumberdaya Manusia, Badan Pengembangan Sumberdaya Kementrian Pariwisata dan Ekonomi Kreatif dengan Balai Konservasi Peninggalan Borobudur, Magelang.

Situngkir, H. (2010). Borobudur was Built Algorithmically. SSRN. doi: 10.2139/ssrn.1672522

Sjamsuddin, H. (2012). Metodologi Sejarah. Yogyakarta, Indonesia: Ombak.

Soekmono. (1976). Chandi Borobudur: A Monument of Mindkind. Paris, France: The Unesco Press.

Suamba, I.B.P. (2016). Cosmology and Cultural Ecology as Reflected in Borobudur Buddhist Temple. Journal of International Buddhist Studies, 6(1), 18-34. doi: 10.14456/ jibs.2015.2

Sundberg, J.R. (2008). Considerations on the Dating of Barabudur Stupa. Journal of the Humanities \& Social Science of Southeast Asia and Oceania, 162(1), 95-132. doi: $10.1163 / 22134379-90003675$

Suwardhi, D., Menna, F., Remondino, F., Hanke, K., \& Akmalia, R. (2015). Digital 3d Borobodur: Integration Of 3d Surveying And Modeling Techniques. ISPRS - International Archives of the Photogrammetry, Remote Sensing and Spatial Information Sciences, XL-5/W7. doi: 10.5194/isprsarchives-XL-5-W7-417-2015

Tylor, E. B. (2016). Primitive Culture Volume I (Dover Thrift Editions). New York, NY: Dover Publications.

United Nations Educational, Scientific and Cultural Organization. (2005) The Restoration of Borobudur. Paris, France: Author.

United Nations Educational, Scientific and Cultural Organization. (2014). Final Report of Revitalization of Community Livelihoods Through Creative Industries and Heritage Tourism. Jakarta, Indonesia: UNESCO Office, Jakarta.

Utomo, B.B. (2011). Buddha di Nusantara. Jakarta, Indonesia: Buddhist Education Centre.

Wayman, A. (1981). Reflections on the Theory of Borobudur as a Mandala. In (L.O. Gomez \& H.W. Woodward, Eds.), Borobudur: History and Significance of a Buddhist Monument. Berkeley: Asian Humanities Press. 